\title{
Angioarchitecture of the coronary arteries in Mazama gouazoubira (G. Fischer, 1814)
}

\author{
Angioarquitetura das artérias coronárias \\ em Mazama gouazoubira (G. Fischer, 1814)
}

\author{
Milena Sorban Zaniboni ${ }^{1}$, W Wilson Viotto-Souza ${ }^{2,3}$ (D), Drielly Gomes Assis Samora ${ }^{(0)}$, \\ Fernanda Coelho Simas Bernardes 4 (D), André Luiz Quagliatto Santos² (D), \\ Amarílis Díaz de Carvalho ${ }^{1}$ (D), Paulo de Souza-Junior ${ }^{1^{*}}$ (1)
}

\begin{abstract}
Mazama gouazoubira is a widely distributed deer in the South American continent. However, studies on its anatomical characteristics are still scarce. The objective of this study was to elucidate the coronary circulation of $M$. gouazoubira. With this aim, after collecting cadavers on highways, twenty-four hearts injected with latex and preserved in formaldehyde at $10 \%$ were dissected. The dissections revealed that all specimens presented left coronary dominance, characterized by the origin of the subsinuous interventricular branch from the circumflex branch of the left coronary artery. The number of ventricular branches originated from branches of the left coronary artery was approximately five times higher than that of the right coronary artery. The occurrence of myocardial bridges was registered in $91.7 \%$ of the individuals, with bridges predominating over the paraconal interventricular branch. The mean length of the paraconal interventricular sulcus was significantly higher in males $(p=0.02)$. The number of atrial branches and ventricular branches, length of myocardial bridges and length of subsinuous interventricular sulcus did not vary significantly between sex. Left coronary dominance and high frequency of myocardial bridges in M. gouazoubira are preponderant anatomical traits also present in different species of Ruminantia suborder. Coronary dominance studies in other South American deer species may confirm the correlation of this trait with the evolutionary history of these animals.
\end{abstract}

KEYWORDS: Cervids; Coronarian dominance; Myocardial bridges; Cardiovascular system; Brown-brocket deer.

RESUMO: Mazama gouazoubira é um cervídeo com ampla distribuição no continente sul americano. Entretanto, estudos sobre suas características anatômicas, ainda, são escassos. Objetivou-se elucidar a circulação coronariana do M. gouazoubira. Para tal, foram dissecados 24 coraçóes injetados com látex e conservados em formaldeído a $10 \%$, obtidos de cadáveres recolhidos em rodovias. As dissecaçôes revelaram que todos os espécimes apresentaram dominância coronariana esquerda, caracterizada pela origem do ramo interventricular subsinuoso, a partir do ramo circunflexo da artéria coronária esquerda. O número de ramos ventriculares originados, a partir de ramos da artéria coronária esquerda, foi aproximadamente cinco vezes maior do que aquele da artéria coronária direita. A ocorrência de pontes de miocárdio foi registrada em 91,7\% dos indivíduos, predominando as pontes sobre o ramo interventricular paraconal. O comprimento médio do sulco interventricular paraconal foi significativamente maior em machos $(p=0,02)$. O número de ramos atriais e ramos ventriculares, comprimento das pontes de miocárdio e comprimento do sulco interventricular subsinuoso, não variaram, significativamente, entre os sexos. A dominância coronariana esquerda e a elevada frequência de pontes de miocárdio no $M$. gouazoubira são traços anatômicos preponderantes, também, em diferentes espécies da subordem Ruminantia. Estudos sobre dominância coronariana em outras espécies de cervídeos sul americanos poderão sugerir a correlação desta característica com a história evolutiva destes animais.

PALAVRAS-CHAVES: Cervídeos; Dominância coronariana; Pontes de miocárdio; Sistema cardiovascular; Veado-catingueiro.

\footnotetext{
UUniversidade Federal do Pampa (UNIPAMPA), Uruguaiana/RS, Brasil

¿Universidade Federal de Uberlândia (UFU), Uberlândia/MG, Brasil

${ }^{3}$ Centro Universitário Presidente Antonio Carlos (UNIPAC), Uberlândia/MG, Brasil

${ }^{4}$ Universidade Estadual de Santa Cruz (UESC), Ilhéus/BA, Brasil

*Corresponding author: paulosouza@unipampa.edu.br

Received: 25/11/2020. Accepted: 20/04/2021
} 


\section{INTRODUCTION}

The blood supply of the heart is provided by the coronary arteries. These occupy the coronary sulcus and emit superficial or intramyocardial branches distributed throughout the organ to irrigate the myocardium. At rest, about $15 \%$ of the total cardiac output of the individual is destined for cardiovascular functioning, and this percentage is significantly higher during intense physical effort (SINGH, 2018). In humans, coronary variations regarding the dominance, caliber, ramifications, and formation of myocardial bridges are widely investigated (LOUKAS et al., 2006; NERANTZIS et al., 1996; PEREZROJAS et al., 2020; RAI; KHANNA; SINGH, 2020).

Historically, anatomical studies emphasize the contribution of major arteries in the irrigation of myocardial tissue (BANCHI, 1904). Coronary dominance can be classified in three ways: left, right, or codominant (balanced or without dominance). Among the methods to classify dominance, there are criteria based on the establishment of which coronary artery originates from each interventricular branch, the extent of the artery beyond the cardiac apex, or the measurements of the length with a count of the number of branches from each coronary artery (SCANSEN, 2017).

Mazama gouazoubira, known as brown-brocket deer, or gray-brocket deer, belongs to the order Artiodactyla, suborder Ruminantia, family Cervidae (BLACK-DECIMA; VOGLIOTTI, 2016). They are ruminants with natural habitat in fields, forests, and riparian forests from various regions of the Americas. Commonly solitary, they differ from the other families of deer in the Brazilian territory by the absence of ramifications in their horns (DUARTE et al., 2012).

Despite the ecological relevance of cervids, descriptions about their anatomical particularities are still scarce. Although there is a preliminary description based on two specimens (GONSALVES; OBERST; BIRCK, 2015), studies with greater anatomical detail, based on wider sampling and with further morphological characteristics such as the number of branches, cardiac dimensions, intraspecific variations, and sexual variations, are still necessary. Anatomical knowledge is extremely important to support veterinary procedures and the understanding of the evolutionary history of the species (SOUZA JR. et al., 2017). Thus, considering the importance of coronary arteries in the blood supply of the heart, the objective of this study was to describe the coronary anatomy in $M$. gouazoubira, establishing the dominance and the branching patterns of these vessels.

\section{MATERIALS AND METHODS}

The sampling of this study consisted of 24 hearts of $M$. gouazoubira, 15 females, 7 males, and 2 individuals in which it was not possible to identify sex. The specimens were collected dead on highways in the states of Minas Gerais (authorization IBAMA SISBIO, n ${ }^{\circ}$. 49266-1) and Rio Grande do Sul (authorization IBAMA SISBIO 33667). According to Brazilian
Law (11,794/2008), the approval by an Ethics Committee on the Use of Animals (CEUA) is only necessary when experimental protocols are carried out with live vertebrate animals. Since the specimens were collected already dead on highways, this experiment was exempted from committee's approval.

For the removal of the hearts, sternotomies were performed and the vessels of the base were sectioned. The hearts were washed in running water and massaged to remove clots. Subsequently, the pericardial sac was removed and the dissection of small stumps of the aorta artery, pulmonary trunk, pulmonary veins and vena cava were performed.

The right and left coronary arteries were stained with latex injections dyed red (Xadrez ${ }^{\circledast}$ liquid dye). The cannulation of the coronary was performed with intravenous catheters (caliber 20,22 or 24 ) and tied with $15 \mathrm{~mm}$ nylon suture thread 2-0 (Procare $^{\circledR}$ ). Latex was injected through the catheters until repletion of the arteries was observed. The hearts were then immersed in $10 \%$ formaldehyde solution for fixation and latex polymerization. After at least 14 days of fixation, the coronary arteries and their branches were dissected, removing the visceral lamina of the serous pericardium, adipose tissue, and cardiac veins.

The nomenclature used in the study was in accordance with the Nomina Anatomica Veterinaria (ICVGAN, 2017), except for the right marginal artery, which was found but it is not listed in the Nomina.

The length of the paraconal interventricular sulcus was measured with a nylon thread over the sulcus, from the root of the pulmonary trunk to the cardiac apex, to follow the ventricular surface. The measurement of the length of the wire was performed with digital caliper (capacity 0-150 mm, resolution $0.01 \mathrm{~mm}$, accuracy $\pm 0.02 \mathrm{~mm}$, ZAAS Precision, Amatools ${ }^{\circledR}$ ).

When myocardial bridges were found, their length was measured using a caliper before removing the myocardium superimposed on the vessel. In cases where the arteries penetrated the myocardium without reappearing on the surface of the heart, it was classified as an intramyocardial course. In addition, in the presence of myocardial bridges or intramyocardial course, the superficial length of the paraconal interventricular branch was measured, from bifurcation with the circumflex branch to the point at which it entered the cardiac muscles.

The ventricular branches of the right coronary artery and paraconal, subsinuous, and circumflex interventricular branches from the left coronary artery were counted. The atrial branches originating from the right coronary artery and circumflex branch were also counted. The occurrence and origin of septal branches, intermediate branches of the circumflex branch, and right marginal artery were registered.

The paraconal and subsinuous interventricular branches were classified according to their extension in apical (when they reached the cardiac apex), pre-apical (when they did not extend to the apex), or post-apical (if they exceeded the sulcus of origin invading the opposite side). 
The numerical variables obtained in the present study were tabulated in BioEstat $5.3^{\circledR}$ software spreadsheets for the calculation of descriptive statistics (arithmetic mean and standard deviation) and Student's t-test to compare the means between sex. It was considered significant when $p<0.05$. Data were expressed by a simple percentage calculation.

\section{RESULTS}

In all the hearts of $M$. gouazoubira it was verified that the coronary arteries emerged from the aortic sinuses, located over the aortic semilunar valve, in the aortic bulb. The left coronary artery was observed between the root of the pulmonary trunk and the left auricle, towards the coronary sulcus, where it emitted the paraconal and circumflex interventricular branches (Figure 1).

Among the 24 specimens in the sample, 15 of them had at least one myocardial bridge $(62.5 \%)$, five had two bridges (20.9\%), two had three bridges (8.3\%), and in only two hearts there were no myocardial bridges $(8,3 \%)$.

The paraconal interventricular branch occupied the sulcus of the same name, directing itself to the cardiac apex, and

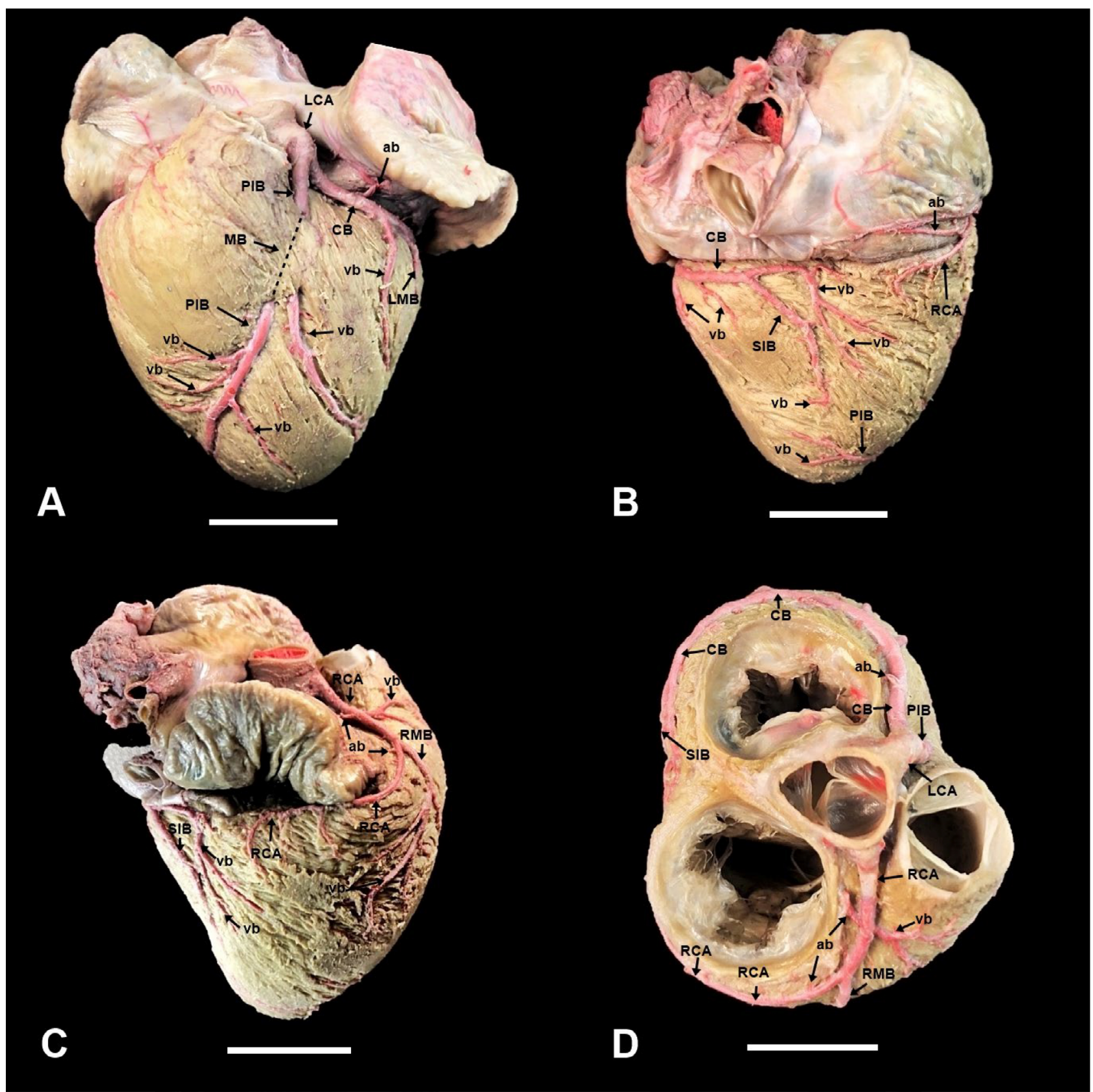

Figure 1. Photomacrographs of the heart of an adult, female, Mazama gouazoubira specimen. Left surface with myocardial bridge (A); right surface over the subsinuous interventricular groove (B); right craniolateral view (C); dorsal view of the heart base after removal of the auricles (D). Left coronary artery (LCA); myocardial bridge (MB); paraconal interventricular branch (PIB); ventricular branches (vb); atrial branches (ab); circumflex branch of left coronary artery (CB); left marginal branch (LMB); right coronary artery (RCA); right marginal branch (RMB); subsinuosal interventricular branch (SIB). Scale bar: 20 mm. 
provided ventricular and septal irrigation through a septal branch in 21 (87.5\%) individuals. In 13 (54.2\%) specimens, the paraconal interventricular branch was classified as postapical and in $11(45.8 \%)$ as apical. There was no pre-apical paraconal interventricular branch.

In males $(n=7)$ the mean length of the paraconal interventricular branch was $8.9 \pm 1.7 \mathrm{~cm}$ and in females $(\mathrm{n}=15)$ $7.0 \pm 1.7 \mathrm{~cm}$, being the only measurement with significant difference between sex $(p=0.02)$. In 22 specimens (91.7\%) the paraconal interventricular branch formed myocardial bridge. In two individuals (8.3\%), one male and one female, did not form a myocardial bridge; the course of the paraconal interventricular branch was entirely intramyocardial. There were no cases in which the paraconal interventricular branch was totally epicardial. The paraconal interventricular branch was epicardial by an average of $0.4 \pm 0.3 \mathrm{~cm}$ until it deepened into the myocardium and formed a myocardial bridge $(n=22)$ or, rarely, followed an intramyocardial course $(\mathrm{n}=2)$.

Regarding the circumflex branch, it coursed totally epicardially in the coronary sulcus in 10 specimens (41.7\%), totally intramyocardially in seven (29.1\%), formed one myocardial bridge in six (25\%), and two myocardial bridges in one (4.2\%). An intermediate branch of the circumflex branch was found in $18(75 \%)$ hearts. The circumflex branch continued to the subsinuous interventricular sulcus forming the subsinuous interventricular branch in all individuals, defining a left dominance.

The subsinuous interventricular branch had a course in the corresponding sulcus, and was classified as pre-apical in a half $(50 \%)$ of specimens and as apical in the other half. There was no post-apical subsinuous interventricular branch. No myocardial bridges were found in the subsinuous interventricular branch, but in 14 (58.3\%) individuals the course was entirely intramyocardial, while in 10 (41.7\%) was totally epicardially.

The right coronary artery emerged between the pulmonary trunk and the right auricle toward the coronary sulcus. This path was totally epicardial in 18 hearts (75\%), intramyocardial in four $(16.7 \%)$ and formed a myocardial bridge in two (8.3\%). The lengths of myocardial bridges and the intramyocardial stretch of the right coronary artery and major coronary branches are reported in Table 1.

Table 1. Average length \pm standard deviation (in $\mathrm{cm}$ ) of intramyocardial (IM) path and myocardial bridges (MB) found in the paraconal interventricular branches (PIB), circumflex (CB), subsinuous interventricular (SIB) and in the right coronary artery $(R C A)$ in Mazama gouazoubira $(n=24)$.

\begin{tabular}{c|c|c|c|c} 
& PIB & CB & SIB & RCA \\
IM & $\begin{array}{c}8.4 \pm 1.3 \\
(n=2)\end{array}$ & $\begin{array}{c}5.0 \pm 1.1 \\
(n=6)\end{array}$ & $\begin{array}{c}3.4 \pm 0.8 \\
(n=14)\end{array}$ & $\begin{array}{c}4.6 \pm 1.8 \\
(n=4)\end{array}$ \\
\hline \multirow{2}{*}{ MB } & $2.7 \pm 1.1$ & $1.3 \pm 0.4$ & & $2.2 \pm 0.7$ \\
& $(n=22)$ & $(n=6)$ & - & $(n=2)$ \\
\hline
\end{tabular}

The count of the atrial and ventricular branches originated directly or indirectly from the coronary arteries in $M$. gouazoubira is summarized in Table 2 . The average number of ventricular branches originated from branches of the left coronary artery ( 24.3 branches) was practically five times higher than the right coronary artery ( 4.9 branches). There was no difference between the numbers of branches in the comparison between sex $(p>0.05)$.

Anastomoses between the interventricular branches occurred in only three (12.5\%) cadavers. In 20 (83.3\%) individuals, there was the presence of a right marginal artery arising from the right coronary artery.

\section{DISCUSSION}

Left coronary dominance was a consistent finding in the hearts of the twenty-four $M$. gouazoubira specimens of the present study. This characteristic is identical to that described for cattle, sheep, and goat (CORREIA-OLIVEIRA; HERNANDEZ; ABIDU-FIGUEIREDO, 2013; GHOSHAL, 1986; SINGH, 2020). In these species, the left coronary artery emits the paraconal interventricular branch and the circumflex branch, the last one originates the subsinuous interventricular branch. The branches of the left coronary artery formed about an average of 25 ventricular branches, while the right coronary artery originated an average of only five ventricular branches. This corroborates the left dominance based also on the criteria of the number of ventricular branches. Among domestic mammals, ruminants and dogs have left dominance, while pigs and horses have balanced coronary circulation (SINGH, 2020). Among wild ruminants, camels (PÉREZ et al., 2018) and alpacas (YUAN et al., 2009) were described with balanced irrigation in studies with ten and eleven specimens, respectively. In contrast, a specimen of Rothschild Giraffe (PÉREZ et al., 2008) was revealed with left domain.

Descriptions of coronary anatomy in deer are scarce. As in the present study, Gonsalves et al. (2015) reported left coronary dominance in two hearts of $M$. gouazoubira. In the Blastocerus dichotomus, Machado et al. (2002) revealed left coronary dominance after dissection of six specimens. However, Vazquez et al. (2019) demonstrated balanced coronary irrigation when dissecting 20 specimens of Ozotoceros bezoarticus.

Table 2. Mean \pm standard deviation of the number of atrial branches (ab) and ventricular (vb) from the left coronary artery (LCA) through the paraconal interventricular branches (PIB), circumflex (CB) and subsinuous interventricular branches (SIB) and from the right coronary artery (RCA) in Mazama gouazoubira $(n=24)$.

\begin{tabular}{c|c|c|c|c|c}
\multicolumn{5}{c|}{ LCA } & \multirow{2}{*}{ RCA } \\
\cline { 1 - 5 } & PIB & CB & SIB & PIB+CB+SIB & \\
\cline { 1 - 5 } $\mathrm{ab}$ & - & $3.4 \pm 1.3$ & - & 3.4 & $3.4 \pm 1.6$ \\
\hline $\mathrm{vb}$ & $13.2 \pm 3.8$ & $4.8 \pm 1.7$ & $6.3 \pm 2.5$ & 24.3 & $4.9 \pm 1.9$ \\
\hline
\end{tabular}


In the analysis of the evolutionary history of South American deer, M. gouazoubira and B. dichotomus are phylogenetically closer and retain this characteristic of left coronary dominance, while $O$. bezoarticus would belong to a more distant group and has balanced irrigation. Such groups had a common ancestor and would have diverged in the Pliocene (DUARTE; GONZÁLES; MALDONADO, 2008). Future studies of coronary anatomy with some other species of South American deer (Hippocamelus bisulcus, Hippocamelus antisensis and Mazama nemorivaga) may elucidate the hypothesis that the pattern of coronary irrigation in South American deer correlates with the evolutionary history of these species.

Compared to the average number of ventricular branches originating from different coronary branches, the M. gouazoubira presented very similar numbers to domestic goats (MOURA JR. et al., 2009), possibly because they are both ruminants and with similar body size and heart size. However, the different locomotor habits and the more intense muscular effort of free-living deer would make it possible to speculate that $M$. gouzoubira had more ventricular branches.

In the M. gouazoubira species, it is well known that males are larger and probably territorial, with their home range overlapping the areas of two or more females (BLACK-DÉCIMA, 2000). Thus, it could be speculated that coronary irrigation could exhibit differences between sexes to satisfy an unequal myocardial demand. However, the mean number of ventricular branches did not differ between males and females of $M$. gouzoubira. If there are adaptations to meet the supposed greater requirements for myocardial irrigation, they may be related to the caliber of the vessels or to other physiological variables, and not necessarily to the number of branches.

The functional or pathological relevance of myocardial bridges is still poorly understood. In humans, myocardial bridges (PM) are common and often clinically asymptomatic. In some cases, they may be associated with arrhythmias, angina, and heart attacks followed by death (PEREIRA et al., 2010). On the other hand, some argue that they may favor venous return in the heart (BERTOLINI; PRATES; MIRANDANETO, 1999) or even have a protective effect against atherosclerosis (KOSINSKI; GRZYBIAK, 2001). Despite the high frequency of myocardial bridges in animals, descriptions remain incipient and no substantial functional, clinical, or pathological correlations have been found.

In M. gouazoubira, $91.7 \%$ of the individuals had at least one myocardial bridge. This finding seems to be a morphological characteristic of the heart of the Ruminantia suborder, since the occurrence of myocardial bridges in domestic ruminants has already been well documented in $100 \%$ of the sheep studied of the Ideal (CRUZ et al., 2007) and Awassi (AKSOY; ÖZÜDOGRU; ÖZDEMIR, 2018) breeds, and between 94 and $100 \%$ of bovine hearts (SEVERINO; BOMBONATO, 1992; SEVERINO et al., 1997).
All specimens of $M$. gouazoubira had left dominance and almost all presented myocardial bridge in the paraconal interventricular branch, although no bridges were identified in the subsinuous branch. Among ruminants, the absence of bridges in the subsinuous interventricular branch also occurred in Ideal sheep (CRUZ et al., 2007), although bridges were recorded in 20\% of the Awassi sheep (AKSOY; ÖZÜDOGRU; ÖZDEMIR, 2018).

Teixeira et al. (1979) analyzed fifty human hearts and most $(58 \%)$ had myocardial bridges in the paraconal interventricular branch, which ranged from 0.3 to $5.3 \mathrm{~cm}$, with an average of $2.28 \mathrm{~cm}$. In fact, the occurrence of myocardial bridges predominates in men with left coronary dominance and most commonly appear in the anterior interventricular branch (paraconal) (LOUKAS et al., 2006).

In 28 wild boar hearts, the frequency of myocardial bridges was $57 \%$, with multiple bridges occurring in $31.3 \%$ (NOCETTI et al., 2002). In M. gouazoubira, $91.7 \%$ presented at least one bridge, with hearts with multiple bridges restricted to $29.3 \%$ of the cases.

In B. dichotomus, Machado et al. (2002) revealed that paraconal and subsinuous interventricular branches entered the myocardium and did not reemerge, forming an entirely intramyocardial path. This type of presentation occurred in more than half of the subsinuous interventricular branches of $M$. gouazoubira.

Data on the length of myocardial bridges are still scarce in mammals. In human hearts the average length of myocardial bridges was $3.1 \mathrm{~cm}$ (LOUKAS et al., 2006), in wild boars 1.47 $\mathrm{cm}$ (NOCETTI et al., 2002), in mules $0.96 \mathrm{~cm}$ (RIBEIRO et al., 2009), in dogs $0.60 \mathrm{~cm}$ (FARIAS; SOUSA; GOMES, 2016), in Ideal sheep $2.28 \mathrm{~cm}$ (CRUZ et al., 2007), while in M. gouazoubira ranged from 1.3 to $2.7 \mathrm{~cm}$.

In most (54.2\%) of the M. gouazoubira specimens, the paraconal interventricular branch terminated at the postapical level. The end at this level was also verified in just over half of domestic dogs (OLIVEIRA et al., 2011) and less than half of felines (MONFARED; MOOSAVI; BAZDAR, 2013) and pigs (MOURA JR. et al., 2008). Anastomoses between the interventricular branches occurred in only three (12.5\%) cadavers of M. gouazoubira. This percentage can be considered low when compared to the occurrence in $80 \%$ of domestic dogs (BÜLL; MARTINS, 2002) and in 100\% of Cebus apela primates (RADE; PEREIRA; CARNEIRO-E-SILVA, 2006).

The right marginal artery supplies the right ventricular wall. In individuals in which a right marginal artery has not been identified, ventricular branches of the right coronary artery and of the subsinuous interventricular branch supply the region that would be attributed to the right marginal artery. While $83.3 \%$ of the individuals in this study had a right marginal artery, this vessel was found in $100 \%$ of pigs (MOURA JR. et al., 2008) and in $98.7 \%$ of domestic felines (MONFARED; MOOSAVI; BAZDAR, 2013). However, a 
terminological issue must be pointed out. The frequency of identification of the right marginal artery may be underestimated in the literature, as the Nomina Anatomica Veterinaria does not list it and, thus, some studies may account for it as a ventricular branch.

The subsinuous interventricular branch ended at apical level in half of the M. gouazoubira, and pre-apical in the other half. In felines (MONFARED; MOOSAVI; BAZDAR, 2013), dogs (OLIVEIRA et al., 2011) and pigs (MOURA JR. et al., 2008), the most common presentation is pre-apical, ending at apical level in about $20 \%$ of cases in the three species.

The occurrence of a septal branch originating in the paraconal interventricular branch in $87.5 \%$ of $M$. gouzoubira specimens can be considered high, if considered to have appeared in only 48 to $60 \%$ of domestic dogs (DONALD; ESSEX, 1954; NOESTELTHALLER; PROBST; KONIG, 2007). In dogs and rabbits, some cases of septal branches deriving from the circumflex branch or directly from the left coronary artery have been reported (BAHAR; TIPIRDAMAZ; ELKEN, 2007; DONALD; ESSEX, 1954), but were not seen in the present work.

\section{CONCLUSIONS}

Finally, it can be concluded that the coronary dominance in M. gouazoubira is essentially left. Left dominance may be related to phylogeny, but it needs confirmation from studies with other species of deer in South America. The presence of at least one myocardial bridge, most often in the paraconal interventricular branch, is practically a rule in this species. The functional significance of such dominance needs to be clarified by the documentation of histopathological microlesions or by electrocardiographic studies.

\section{ACKNOWLEDGEMENT}

Coordenação de Aperfeiçoamento de Pessoal de Ensino Superior (CAPES)

\section{REFERENCES}

AKSOY, G.; ÖZÜDOČRU, Z.; ÖZDEMIR, D. A macroanatomic investigation of the coronary arteries and myocardial bridges in Awassi sheep. Eurasian Journal of Veterinary Sciences, v. 34, п. 3, p. 171-177, 2018.

BAHAR, S.; TIPIRDAMAZ, S.; EKEN, E. The distribution of the cardiac veins in Angora rabbits. Anatomia Histologia Embryologia, v. 36, ก. 4, p. 250-254, 2007.

BANCHI, A. Morfologia delle arteriae coronáriae cordis. Italian Journal of Anatomy and Embryology, v. 3, p. 87-164, 1904.

BERTOLINI, S. M. M. G.; PRATES, N. E. V. B.; MIRANDA NETO, M. $H$. Estudo microscópico das pontes de miocárdio sobre as veias cardíacas de suínos. Acta Scientiarum, v. 2l, p. 415-419, 2008.

BLACK-DÉCIMA, P. A. Home range, social structure and scent marking behavior in brown brocket deer in a large enclosure. Mastozoología Neotropical, v. 7, p. 5-14, 2000.

BLACK-DECIMA, P.A.; VOCLIOTTI, A. Mazama gouazoubira. The IUCN Red List of Threatened Species, 2016. Disponível em: <http:/ dx.doi.org/10.2305/IUCN.UK.2016-2.RLTS.T29620A22154584. en>. Acesso em: 18 de out. de 2020.

CORREIA-OLIVEIRA, M.; HERNANDEZ, J. M.; ABIDU-FIGUEIREDO, M. Morfometria cardíaca e distribuição das artérias coronárias em bovinos mestiços. Biotemas, v. 26, n. 2, p. 199-207, 2013.

CRUZ, T. L. et. al. Pontes de miocárdio em ovinos da raça Ideal: freqüência e largura. Ciência Animal Brasileira, v. 8, n. 2, p. 307312,2007

DONALD, D. E.; ESSEX, H. E. Pressure studies after inactivation of the major portion of the canine right ventricle. American Journal of Physiology, v. 176, n. 1, p. 155-161, 1954.
DUARTE, J. M. et al. Avaliação do risco de extinção do Veadocatingueiro Mazama gouazoubira [von Waldheim], 1814, no Brasil. Biodiversidade Brasileira, v. 2, n. 3, p. 50-58, 2012.

DUARTE, J.M. B.; GONZÁLEZS.; MALDONADO J. E. The surprising evolutionary history of South American deer, MolecularPhylogenetics and Evolution. Molecular Phylogenetics and Evolution, v. 49, n. 1, p. 17-22, 2008.

FARIAS, E. L. P.; SOUSA, R. S. DE; GOMES, F. G. F. L. R. Ocorrência e Morfometria de pontes de miocárdio em cães. Archives of Veterinary Science, v. 22, n. 4, p. 82-91, 2016.

GHOSAL, N. G. Coração e artérias do ruminante. In: GETTY, R. Anatomia dos animais domésticos. 5. ed. Rio de Janeiro: Guanabara Koogan, 1986. p 900-959.

GONSALVES, B. G.; OBERST, J. S. P.; BIRCK, A. J. Origem e distribuição das artérias coronárias em veado catingueiro (Mazama gouazoubira). Revista Científica Eletrônica de Medicina Veterinária, v. 24, p. 1-10, 2015.

ICVGAN. International Committee on Veterinary Gross Anatomy Nomenclature. Nomina Anatomica Veterinaria. 6. ed. Hannover: Editorial Committee, 2017.160p.

KOSINSKI, A.; GRZYBIAK, M. Myocardial bridges in the human heart: morphological aspects. Folia Morphologica, v. 60, n. 1, p. 65-68, 2001.

LOUKAS, M. et al. The relationship of myocardial bridges to coronary artery dominance in the adult human heart. Journal of Anatomy, v. 209, n. 1, p. 43-50, 2006.

MACHADO, M. R F. et al. Intramyocardial course of the coronary arteries in the marsh deer (Blastocerus dichotomus). Brazilian Journal of Veterinary Research and Animal Science, v. 39, n. 6 , p. 285-287, 2002. 
MONFARED, A. L.; MOOSAVI, S.; BAZDAR, A. The macroanatomy of coronary arteries in the iranian native cats. Global Veterinaria, v. 10, п. 4, p 413-416, 2013.

MOURAJUNIOR, P.C. et al. Estudo anatômico das artérias coronárias de suínos Landrace. Pesquisa Veterinária Brasileira, v. 28, п. 2, p. 103-107, 2008.

MOURAJUNIOR, P.C. et al. Estudo anatômico das artérias coronárias em caprinos. Pesquisa Veterinária Brasileira, v. 29, n. 4, p. 358362, 2009.

NERANTZIS, C. E. et al. Functional dominance of the right coronary artery: incidence in the human heart. Clinical Anatomy, v. 9, n. l, p. 10-13, 1996.

NOCETTI, L. M. et al. Pontes de miocárdio em corações de javali. Brazilian Journal of Veterinary Research and Animal Science, v. 39, п. 2, p. 66-73, 2002.

NOESTELTHALLER, A.; PROBST, A.; KÖNIG, H. E. Branching patterns of the left main coronary artery in the dog demonstrated by the use of corrosion casting technique. Anatomia Histologia Embryologia, v. 36, n. 1, p. 33-37, 2007.

OLIVEIRA, C. L. S. et al. Anatomical Indicators of Dominance between the Coronary Arteries of Dogs. International Journal of Morphology, v. 29, n. 3, p. 845-849, 2011.

PEREIRA, A. B. et al. Myocardial bridging: therapeutic and clinical development. Arquivos Brasileiros de Cardiologia, v. 94, n. 2, p. 175-181, 2010.

PÉREZ, W. et al. Heart anatomy of Giraffa camelopardalis rothschildi: a case report. Veterinarni Medicina, v. 53, n. 3, p. 165-168, 2008.

PÉREZ, W. et al. Gross anatomy of the heart of the alpaca (Vicugna pacos, Linnaeus 1758). Anatomia Histologia Embryologia, v. 47, п. 2, p. 110-118, 2018.

PEREZ-ROJAS, F. et al. Biometric Analysis of Healthy Coronary Arteries in a Chilean Population: AnAngiographic Study. International Journal of Morphology, v. 38, n. 6, p. 1797-1802, 2020.
RADE, W.; PEREIRA, W. F; CARNEIRO E SILVA, F. O. Origem, trajeto, ramificações e distribuição dos ramos ventriculares da artéria coronária direita no macaco prego (Cebus apella). Bioscience Journal, v. 22, n. 2, p. 133-137, 2006.

RAI, G.; KHANNA, S.; SINGH, R. Myocardial bridging in the course of coronary arteries and its clinical significance. Asian Journal of Medical Sciences, v. 11, n. 6, p. 58-62, 2020.

RIBEIRO, A. L. C. at al. Biometria de pontes de miocárdio em muares (Equus caballus x Equus asinus - Linnaeus 1758). Biotemas, v. 22 , ก. 3, p. 177-184, 2009.

SCANSEN, B. A. Coronary Artery Anomalies in Animals. Veterinary Sciences, v. 4, n. 2, p. 1-18, 2017.

SEVERINO, R. S.; BOMBONATO, P. P. Ocorrência de pontes de miocárdio em bovinos das raças Gir, Guzerá, Indubrasil e Nelore. Brazilian Journal of Veterinary Research and Animal Science, v. 29, п. 1, p. 13-30, 1992.

SEVERINO, R. S. et al. Pontes de miocárdio em bovinos azebuados. Brazilian Journal of Veterinary Research and Animal Science, v. 34, n. 5, p. 288-291, 1997.

SINGH, B. Dyce, Sack and Wensing's Textbook of Veterinary Anatomy. 5. ed. Missouri: Elsevier, 2018. 1606p.

SOUZAJUNIORP.et al.Osteología del miembro torácico de la corzuela parda Mazama gouazoubira (G. Fischer, 1814) (Cetartiodactyla: Cervidae). International Journal of Morphology, v. 35, n. 3, p. 1000-1009, 2017.

TEIXEIRA, J. P. et al. Artéria coronária descendente anterior com trajeto intramiocárdico: estudo anatômico e implicações cirúrgicas. Arquivos Brasileiros de Cardiologia, v. 33, n. 1, p. 334-339, 1979.

VAZQUEZ N. et al. Gross Anatomy of the Heart of Pampas Deer (Ozotoceros bezoarticus, Linnaeus 1758). Journal of Morphological Sciences, v. 36, п. 3, p. 190-195, 2019.

YUAN, G. et al. Macroanatomy of coronary arteries in Bactrian camel (Camelus bactrianus). Veterinary Research Communications, v. 33, п. 4, p. 367-377, 2009. 